\title{
TINJAUAN SOSIAL EKONOMI DAN BUDAYA IBADAH QURBAN
}

\author{
Evi Marlina*, Isran Bidin , Zul Azmi, Adriyanti Agustina Putri, Rama Gita Suci \\ Prodi Akuntansi, Fakultas Ekonomi dan Bisnis UMRI \\ email: evimarlina@umri.ac.id
}

\begin{abstract}
Sacrifice worship is a slaughtering service which is held every year by Muslims around the world which is approved when it is prepared with a big day. Thus, qurban worship will have a direct impact on the socioeconomic and cultural conditions of the communities where qurban worship is performed. From the socio-economic aspects of qurban worship is not only limited to religious rituals but can also be a community economic driver in the procurement of qurban animals. Furthermore, in the socio-cultural aspect is how to worship the qurban can be transformed into a community lifestyle that can be done easily by consumerism experts and excessive lifestyle. The problem that occurs in society is public awareness (pilgrims) about the wisdom of the sacrifice of qurban which is more important from the socio-economic and cultural aspects. This dedication is done to increase public awareness (pilgrims) of the wisdom of the Sacrifice worship especially from the socio-economic and cultural aspects. This activity was carried out at the Istiqlal Mosque, East Sidomulyo Sub-district, Maratoyan Damai Sub-District, Pekanbaru City. Suggestions made are lectures and discussions, namely providing explanatory material tutorials and discussions and providing examples of the management and implementation of qurban worship that can improve the social economy and culture of society.
\end{abstract}

Keywords: social economy, culture, worship qurban

\begin{abstract}
Abstrak
Ibadah qurban merupakan ibadah pemotongan hewan qurban yang diselenggarakan setiap tahun oleh umat muslim diseluruh dunia tepatnya saat merayakan hari besar aidil adha. Dengan demikian, ibadah qurban secara tidak langsung akan berdampak terhadap kondisi sosial ekonomi dan budaya masyarakat dimana ibadah qurban tersebut dilaksanakan. Dari aspek sosial ekonomi ibadah qurban tidak hanya hanya sebatas ritual kegamaan semata tetapi juga bisa sebagai penggerak perekonomian masyarakat terutama dalam pengadaan hewan qurban.. Selanjutnya dalam aspek sosial budaya adalah bagaimana ibadah qurban dapat mengubah gaya hidup umat menjadi lebih sederhana yang jauh dari sifat konsumerisme dan gaya hidup berlebihan. Permasalahan yang selama terjadi di masyarakat adalah kurangnya kesadaran masyarakat (jamaah) tentang hikmah dari ibadah qurban terutama dari aspek sosial ekonomi dan budaya. Pengabdian ini dilakukan untuk meningkatkan kesadaran masyarakat (jamaah) terhadap hikmah dari ibadah qurban teruitama dari aspek sosial ekonomi dan budaya. Kegiatan ini dilakukan di mesjid Istiqlal Kelurahan Sidomulyo Timur, Kecataman Marpoyan Damai, Kota Pekanbaru. Pendekatan yang dilakukan adalah ceramah dan diskusi, yaitu dengan memberikan penjelasan materi secara tutorial dan diskusi serta memberikan contoh pengelolaan dan pelaksanaan ibadah qurban yang dapat meningkatkan dampak sosial ekonomi dan budaya masyarakat .
\end{abstract}

Keywords: sosial ekonomi, budaya, ibadah qurban

\section{PENDAHULUAN}

Ibadah qurban setiap tahunnya dilaksanakan bertepatan dengan pelaksanaan ibadah haji yaitu pada bulan
Dzulhijah yang merupakan hari besar umat islam yang disebut hari aidul adha. Pada hari raya ini sebagian besar umat islam akan menyembelih hewan kurban 
khususnya diselenggarakan bagi umat muslim yang mampu, sebagaimana diperintahkan Allah SWT dalam surah al-Kautsar (108): 1-2."Sesungguhnya Kami telah memberikan kepadamu nikmat yang banyak. Maka dirikanlah shalat karena Tuhan-mu dan berkurbanlah."

Makna dari ibadah kurban sangat dalam dan luas. Bukan sekadar ibadah tahunan yang bernilai spiritual-sosial. Lebih jauh lagi, esensi dari kurban adalah membangun kerangka ekonomi dan budaya umat Islam

\section{Nilai sosial ekonomi}

Sebagaimana halnya zakat, infak, sedekah, dan wakaf, kurban memiliki kekuatan penggerak ekonomi. Tentu saja itu dapat terjadi jika dikelola dengan baik. Sayangnya, hingga saat ini belum ada lembaga nasional yang secara khusus menangani kurban. Atau paling tidak, ada koordinasi antar lembaga dalam melaksanakan kurban Dari data tiap lembaga tersebut, dapat diperoleh informasi di mana saja daerah yang banyak melakukan ibadah kurban, di mana yang tidak mendapatkan hewan kurban, siapa saja yang berkurban dan penerimanya, berapa jumlah dan datadata terkait lainnya. Ini sangat penting karena jika tidak dilakukan, ibadah kurban sepertinya kurang memiliki dampak ekonomi dan sosial apa pun. Setiap tahun kegiatan kurban hanya membeli, menyerahkan kepada panitia, dan membagikannya, setelah itu selesai.

Selama ini koordinasi yang baik antar lembaga atau organisasi kemasyarakatan islam belum terlaksana. Oleh karena itu perlu adanya partisipasi pihak-pihak yang berkepentingan seperti Majelis Ulama Indonesia (MUI) memberikan arahan pentingnya koordinasi data dan program dalam pelaksanaan ibadah kurban. Dengan demikian, pembenahan sistem organisasi dan manajemen kurban mutlak harus dilakukan. Jika saja pengelolaan kurban dilakukan dengan sistem manajemen yang sangat baik, maka akan menjadi suatu strategi ekonomi umat yang luar biasa. Asumsikan saja, jika hanya 100 ribu orang yang melakukan ibadah kurban, maka ada dana lebih dari Rp 200 miliar yang berputar. Bisa saja jumlahnya lebih dari 500 ribu orang karena ada banyak yang berkurban lebih dari satu. Artinya, ada dana Rp 1 triliun lebih yang berputar dalam waktu menjelang dan selama kegiatan ibadah kurban dilakukan. Belum lagi jika kita menghitung multiplayer effect-nya.

Hingga kini, tidak diketahui pasti, berasal dari mana hewan kurban yang diperdagangkan. Agar sesuai syariah, pemasok hewan kurban adalah ormas Islam atau lembaga zakat. Jika pun pemain kecil tetap ada, harus dikoordinasikan dan dipayungi oleh lembaga ekonomi umat yang besar, baik itu dikelola dalam bentuk koperasi syariah atau lembaga lainnya. Jangan sampai, peluang bisnis besar ini dipegang segelintir orang yang tak ada kontribusi dan bukan bagian dari umat Islam. Sepertinya rumit, tapi ini sudah seharusnya dapat dilakukan. Menurut Iu Rushana, (2019 ada beberapa argumentasi mengapa pengelolaan ibadah kurban harus diperbaiki manajemennya. 1) makna spiritual kurban itu adalah mengekang sifat kebinatangan, duniawi yang dominan. Jika ego antar lembaga masih tetap dipelihara, tidak mau sinergi satu sama lain, sama saja dengan memelihara sifat duniawi. 2) lembaga atau panitia hanyalah pihak ketiga yang diamanahi untuk mengelola dan memfasilitasi ibadah kurban itu. Harusnya koordinasi data dan sinergi program dapat dilakukan karena kurban dilakukan setiap tahun. 3) kurban, sebagaimana zakat, infak, sedekah, dan wakaf adalah bentuk kepedulian yang berpunya (aghniya) kepada yang kekurangan (dhuafa). Tujuannya mendorong 
pemerataan kesejahteraan ekonomi dan sosial. Harusnya bisa dibentuk panitia kurban nasional, daerah hingga tingkat DKM (masjid). 4) kurban harus jadi salah satu pemicu lahirnya industri peternakan dan perdagangan milik umat. Sesuai ajaran islam bahwa umatnya untuk produktif dan memiliki nilai manfaat besar. 5) secara historis, Rasulullah SAW dan sahabat kebanyakan adalah peternak dan penggembala. Dan ini merupakan potensi ekonomi yang tidak akan habis karena kebutuhan akan daging dan susu umat tidak akan pernah berkurang

Nilai sosial budaya

Makna simbolik kurban adalah mengekang sifat kebinatangan dan keduniawian. Kurban hendaknya menjadi nilai budaya untuk menjaga dari kecenderungan konsumerisme dan gaya hidup berlebihan (boros). Budaya hidup sederhana harus dijadikan keseharian umat. Inilah salah satu strategi kebudayaan yang mendesak dilakukan. Umer Chapra dalam bukunya Islam and Economic Development menyatakan, umat Islam harus bersikap kritis dan mampu membedakan antara kebutuhan yang penting dan yang kurang penting. Sehingga, dapat dibedakan antara kebutuhan dengan kemewahan.

Dari perspektif budaya Islam, kurban artinya sikap budaya yang mengedepankan kebutuhan primer dan pentingnya berbagi dengan sesama dibandingkan hidup bermewahmewahan. Umat Islam harus menghindari konsumsi yang berlebihlebihan Dengan ibadah kurban, sifat kebinatangan dibuang dan sifat kepedulian kepada sesama ditumbuhsuburkan. Kaum berlebih dari sisi ekonomi (aghniya) memberikan kontribusi tidak hanya dengan zakat, infak, wakaf, dan sedekah, tetapi juga dengan berkurban.

Bahkan, sebagaimana diajarkan oleh Nabi Ibrahim AS, kecintaan kepada anak dan harta tidak boleh menghalangi kecintaan kepada Allah SWT. Jika Tuhan telah meminta apa pun yang paling dicintai, maka kita harus rela memberikannya. Sebagaimana Nabi Ismail AS, anak terkasih yang ditunggu bertahun-tahun oleh Nabi Ibrahim AS, direlakan untuk disembelih demi menjalankan perintah Tuhan. Cinta kepada Tuhan di atas segala hal yang paling dicintai sekalipun di dunia ini. Jika dikaitkan dengan budaya cinta dunia yang mendominasi saat ini, harusnya kurban memberi nilai yang mampu membuat seorang Muslim mengedepankan kecintaan kepada Tuhan dibandingkan kepada harta benda yang pasti habis dan rusak.

Oleh karena itu, ibadah kurban tidak hanya sekadar ritualitas dan pemenuhan kebutuhan gizi bagi umat yang kurang mampu. Ibadah kurban harus menjadi strategi ekonomi dan kebudayaan agar umat Islam mandiri, sejahtera, dan berdaulat

\section{Permasalahan}

Dari penjelasan di atas dapat diungkapkan beberapa masalah yang umumnya dihadapi oleh pihak mitra terkait dengan hikmah dari ibadah qurban, yaitu:

1. Kurangnya kesadaran masyarakat (jamaah) tentang esensi dari ibadah qurban

2. Hikmah ibadah qurban ditinjau dari aspek sosial ekonomi

3. Hikmah ibadah qurban dari aspek sosial budaya

\section{Tujuan Kegiatan dan rencana pemecahan masalah}

Kegiatan pengabdian ini bertujuan untuk: (1) meningkatkan kesadaran masyarakat (jamaah) tentang esensi dari ibdah qurban, (2) memberikan pemahaman tentang hikmah ibadah qurban ditinjau dari aspek sosial ekonomi (3) memberikan pengetahuan 
tentang hikmah ibadah qurban ditinjau dari aspek sosial budaya

\section{METODE PENGABDIAN}

\section{Tempat dan Waktu}

Kegiatan pengabdian masyarakat tentang tinjauan ibadah qurban dari aspek sosial ekonomi dan budaya di Mesjid Istiqlal Kelurahan Sidomulyo Timur Kecamatan Marpoyan Damai Kota Pekanbaru pada hari Sabtu tanggal 03 Agustus 2019.

\section{Ruang Lingkup dan Objek Pengabdian}

Objek yang menjadi sasaran dari kegiatan pengabdian ini adalah para jamaah dan pengurus Mesjid istiqlal yang merupakan warga RW 02 kelurahan Sidomulyo Timur Kecamatan Marpoyan Damai Kota Pekanbaru.

\section{Pendekatan atau teknik pengabdian}

Kegiatan pengabdian ini dilakukan dengan menggunakan pendekatan ceramah dan diskusi dengan jamaah dan pengurus mesjid terkait tinjauan ibadah qurban dari aspek sosial ekonomi dan budaya. Adapun langkah-langkah yang dilakukan yaitu: (1) meningkatkan kesadaran jamaah dan pengurus tentang esensi ibadah qurban, (2) memberikan pemahaman tentang hikmah ibadah qurban ditinjau dari aspek sosial ekonomi dan (3) memberikan pemahaman tetag hikmah ibadah qurban ditinjau dari aspek sosial budaya.

\section{HASIL DAN PEMBAHASAN}

\section{Pelaksanaan Kegiatan}

Kegiatan pengabdian masyarakat ini diawali dengan persiapan pelaksaan kegiatan, yaitu persiapan tim dengan melakukan rapat koordinasi, pembuatan surat undangan, penyebaran undangan kepada jamaah dan pengurus mesjid Istiqlal.

Kegiatan selanjutnya adalah persiapan kelengkapan kegiatan yang meliputi hal-hal sebagai berikut:
1. Mempersiapkan tempat pelaksanaan kegiatan pengabdian yaitu mesjid istiqlal

2. Mempersipkan media presentasi, yaitu slide presentasi dan Infocus/LCD

3. Pembuatan modul yang akan digunakan dalam ceramah dan diskusi. Modul tersebut dibuat oleh pemateri dengan cakupan berupa materi-materi yang akan diberikan dalam kegiatan pengabdian. Modul tersebut dibuat dalam bentuk tutorial, teori dan contoh pelaksanaan ibadah qurban

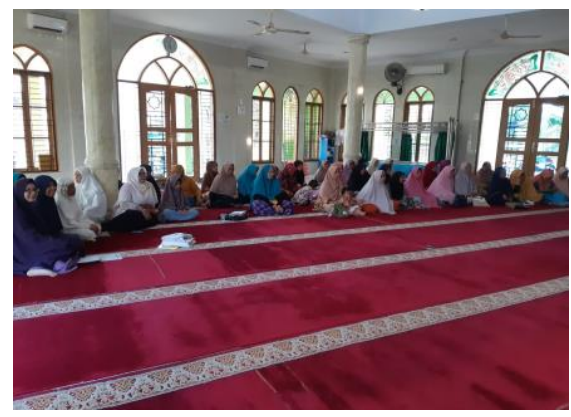

Gambar 1. Pelaksanaan Kegiatan

Dalam kegiatan ceramah dan diskusi tersebut, hanya satu orang pemateri yang memberikan penjelasan tentang tinjauan aspek sosial ekonomi dan budaya ibadah qurban. Permasalahan-permasalahan yang selama ini hanya memandang ibadah qurban hanya proses ritual kegiatan keagamaan semata tanpa menyadari bahwa ibadah qurban juga mempunyai hikmah yang lebih luas .

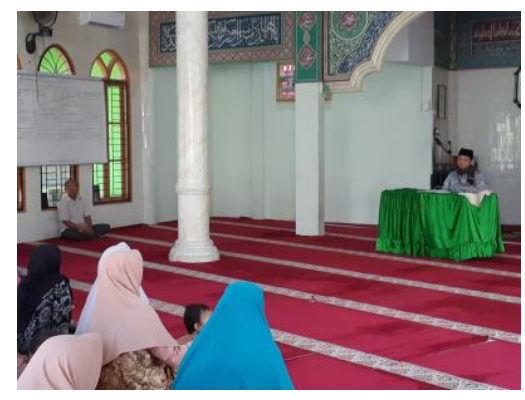

Gambar 1. Kegiatan Ceramah 
Materi pengabdian diberikan selama lebih kurang satu jam dan kemudian dilanjutkan dengan diskusi antara peserta dengan pemateri. Pada sesi diskusi, para peserta terlihat sangat antusias menyampaikan pertanyaanpertanyaan terkait dengan permasalahan tentang ibadah qurban yang telah dilaksanakan selama ini. Sesi diskusi ini memberikan ruang dan suasana kedekatan antara peserta dan panitia maupun pemateri. Banyak peserta yang menyampaikan saran kepada panitia agar kegiatan seperti terus dilakukan dalam rangka untuk meningkatkan pemahaman jamaah dan pengurus mesjid dalam pengelolaan ibadah qurban.

Pada akhir kegiatan, para peserta dan panitia berfoto bersama untuk mengabadikan kegiatan yang dilakukan serta diakhiri dengan makan bersama.

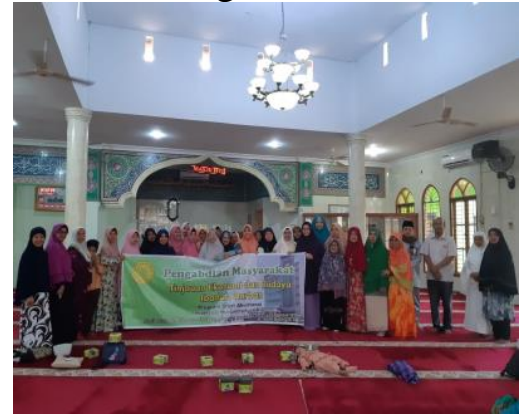

Gambar 3. Foto bersama

\section{SIMPULAN}

Kesimpulan dari kegiatan pengabdian masyarakat bagi jamaah dan pengurus mesjid Istiqlal di Kelurahan Sidomulyo Timur Kecamatan Marpoyan Damai Kota Pekanbaru untuk program Tinjauan sosial budaya dan ekonomi ibadah qurbanadalah sebagai berikut.

a) Peserta pelatihan sangat antusias ketika mengikuti pengabdian berupa ceramah dan diskusi. Para peserta dapat melihat manfaat pengabdian inii, yakni menambah pengetahuan pada hikmah ibadah qurban ditinjau dari asepk sosial budaya dan ekonomi. b) Berdasarkan sharing yang dilaksanakan pada saat diskusi, tidak ada kesan buruk dari peserta selama pelaksanaan pengabdian, baik dari segi sarana dan prasarana maupun penyampaian materi, hanya saja perlu dibuat dalam skala yang lebih luas.

c) Pengabdian selanjutnya tetap diarahkan pada sharing masalah keilmuan dan praktik pengelolaan ibadah qurban yang dapat meningkatkan potensi ekonomi masyarakat. Oleh karena itu, pengembangan pengabdian selajutnya kemungkinan akan diarahkan pada pendampingan pengelolaan ibadah qurban yang dapat meningkatkan kesejahteraan masyarakat.

\section{UCAPAN TERIMA KASIH}

Penulis mengucapkan terima kasih dan apresiasi yang sebesar-besarnya kepada Dekan Fakultas Ekonomi dan Bisnis dan pengurus dan jamaah mesjid Istiqlal yang telah membantu mensukseskan terlaksananya kegiatan pengabdian ini dengan lancar.

\section{DAFTAR PUSTAKA}

[1] Surat al Kautsar ayat 1 \& $2 \mathrm{Al}$ Quran.

[2] Iu Rushana, Budaya dan Ekonomi Qurban, Republika.co.id, Koran Minggu 21 Juli 2019

[3] Umer Chapra (2008) Islam and Economic Development. 